Rua Jardim Federação, n. 334, ap. 101 40231 -060 - Federação - Salvador - BA leandroaalmeida@hotmail.com

\section{REPERCUSSÃO DA EXPANSÃO DA FICÇÃO POPULAR NO BRASIL DOS ANOS 1930*}

\author{
Leandro Antônio de Almeida** \\ Universidade Federal do Recôncavo Baiano \\ Cachoeira - Bahia - Brasil
}

\title{
Resumo
}

O objetivo deste artigo é analisar a repercussão no Brasil, nas décadas de 1930 e 1940, dos gêneros destinados ao grande público, em especial daqueles que hoje consideramos de entretenimento como o policial, o sentimental e as aventuras. As fontes utilizadas serão as opiniões de escritores, editores e intelectuais publicadas em jornais e revistas editadas em São Paulo e Rio de Janeiro. Primeiramente, vamos analisar como a expansão do mercado editorial pautou-se nesses gêneros, como também perceberam editores, escritores e livreiros da época. Em seguida, consideraremos suas opiniões sobre o papel desses gêneros para a cultura letrada no Brasil. Mostraremos posicionamentos que recusam qualquer valor a essa ficção, outros que restringem sua função ao entretenimento ou degrau para formação do leitor erudito, até mesmo as tentativas de nacionalização dessas histórias escritas por escritores estrangeiros e difundidas no Brasil da época.

\section{Palavras-chave}

Literatura de entretenimento - mercado editorial - leitura.

* Este artigo decorre da pesquisa de doutorado defendida em 2013 sob orientação do prof ${ }^{o}$ dr. Elias Thomé Saliba.

${ }^{* *}$ Doutor em História Social pela FFLCH/USP, professor do curso de Licenciatura em História e vice-coordenador do Programa de Mestrado Profissional em História da África, da Diáspora e dos Povos Indígenas do Centro de Artes, Humanidades e Letras (CAHL) da Universidade Federal do Recôncavo da Bahia (UFRB). 
Rua Jardim Federação, n. 334, ap. 101 40231-060 - Federação - Salvador - BA leandroaalmeida@hotmail.com

\section{REPERCUSSION \\ OF PULP FICTION \\ SPREADING IN \\ BRAZILIAN 1930s}

\author{
Leandro Antônio de Almeida
}

Universidade Federal do Recôncavo Baiano

Cachoeira - Bahia - Brazil

\begin{abstract}
This paper aims to analyze, in 1930s and 1940s Brazil, the reception of broad readers fiction genres, especially those nowadays classified as pulp fiction like detective, love and adventure stories. The sources used are writers, publishers and intellectuals opinions published in newspapers and magazines of Rio de Janeiro and São Paulo. First, we will analyze how publishing expansion was led by those genres, as also publishers, writers and booksellers of that time have perceived it. Second, we will consider their opinion about the role of those genres to literacy in Brazil. We will show positions that refuse any value of this fiction, others that limit its function to entertainment or degree to form high literature reader, and those sympathetic that try to nationalize those narratives written by foreign writers and widespread in Brazil of that time.
\end{abstract}

\title{
Keywords
}

Pulp fiction - publishing - reading. 


\section{Introdução}

No final dos anos 1980, ao refletir sobre a ausência de uma vigorosa literatura de entretenimento no país, José Paulo Paes provocou os críticos e escritores brasileiros. Aos primeiros acusava pela ferocidade com que atacavam autores fora dos padrões da literatura erudita, tomando como exemplo José Mauro de Vasconcelos, autor de Meu pé de laranja lima:

A agressividade com que certos críticos se voltaram contra ele, julgando-lhe o desempenho unicamente em termos de estética literária, em vez de analisá-lo pelo prisma da sociologia do gosto e do consumo, mostra a miopia de nossa crítica para questões que fujam ao quadro da literatura erudita.

Já os escritores apenas buscavam glória erudita:

...consola-os ter o nome registrado nas páginas da história literária, no melhor dos casos, ou, no pior, pertencer a alguma academia de letras, federal, estadual, municipal ou até mesmo distrital. Numa cultura de literatos como a nossa, todos sonham ser Gustave Flaubert ou James Joyce, ninguém se contentaria em ser Alexandre Dumas ou Agatha Christie.

Ao se basear nas reflexões de Umberto Eco sobre o tema, José Paulo Paes procurava desfazer um preconceito arraigado em boa parte da crítica e dos escritores brasileiros, que associavam literatura de entretenimento a lixo cultural. Paes entendia que o entretenimento exigia competências narrativas para atender o leitor simpatizante e tinha função importante na formação de um público erudito: preenchia uma lacuna na qual a escola falhava por atrelar a leitura aos deveres e questionários, transformando o prazer em obrigação. Logo:

...é em relação a esse nível superior, aliás, que uma literatura média de entretenimento, estimuladora do gosto e do hábito da leitura, adquire o sentido de degrau ${ }^{1}$ de acesso a um patamar mais alto onde o entretenimento não se esgota em si, mas traz consigo um alargamento da percepção e um aprofundamento da compreensão das coisas do mundo. ${ }^{2}$

\footnotetext{
1 Por isso, a concepção de Paes ficou conhecida como teoria do degrau. REIMÃO, Sandra. Sobre a noção de best-seller. Comunicação e Sociedade. São Paulo: Instituto Metodista de Ensino Superior (IMS), ano X, $\mathrm{n}^{\circ} 18,1991$, p. 53-60.

2 PAES, José Paulo. Por uma literatura brasileira de entretenimento. In: Idem. A aventura literária. São Paulo: Companhia das Letras, 1990, p. 25-38. Citação desta última, grifo do autor.
} 
A literatura de entretenimento, para José Paulo Paes, era um modelo a ser adotado porque conseguia criar esse prazer de maneira despretensiosa ao valer-se de narrativas envolventes numa linguagem acessível. Daí o problema: os literatos do país contribuíam para minar seu próprio ofício ao boicotar um potencial veículo de expansão do seu público. O desprezo por autores como José Mauro de Vasconcelos, Alexandre Dumas ou Agatha Christie, para Paes, tratava-se "obviamente de um erro de perspectiva" porque "da massa de leitores destes últimos autores é que surge a elite dos leitores daqueles [como Flaubert e Joyce], e nenhuma cultura realmente integrada pode se dispensar de ter, ao lado de uma vigorosa literatura de proposta, uma não menos vigorosa literatura de entretenimento" ${ }^{3}$ A provocação de Paes era um chamado aos escritores para uma tarefa de utilidade pública e cultural, atrelada à formação de leitores, vista como urgente no final dos anos $1980 .{ }^{4}$

Numa espécie de programa de pesquisa, Paes esboçou algumas interpretações históricas sobre o fenômeno. Inicialmente, traçou a gênese da cisão entre literatura de proposta e aquela voltada para o gosto do público. Paes remonta sua origem ao período do naturalismo literário, “quando os temas da patologia social e individual levam o romancista a chocar os preconceitos do público burguês, provocando o afastamento histórico de um e outro". A cisão teria se agravado até um ponto irreparável no modernismo através dos "vanguardistas contestando polemicamente os valores tradicionais da arte e ensaiando meios revolucionários de expressão". Afinal,

a prosa experimental de Oswald e Mário de Andrade jamais conseguiu interessar o grande público, que ia satisfazer seus gostos mais convencionais numa literatura preocupada tão-só em lisonjeá-los, o que não era bem o caso do romance nordestino de 30, voltado antes para a denúncia social.

\section{Daí porque}

Não por acaso as décadas de 30 e 40 assistem ao aparecimento das grandes coleções de literatura de entretenimento: a coleção Biblioteca das Moças, de romances sentimentais; as coleções Terramarear e Paratodos, de romances de aventuras e ficção científica; as cole-

\footnotetext{
PAES, José Paulo, op. cit., 1990, citações entre p. 34 e 37.

${ }^{4}$ Ainda na linha de Umberto Eco, para Paes a cultura de proposta seria marcada pelos critérios de originalidade, de uma "visão de mundo singular e inconfundível" e por uma obra que exigisse esforço de interpretação pelo leitor e um desafio a seus valores. Já a literatura de massa prima pelos recursos expressivos que agradem o leitor médio que, por pouco originais, não exigem esforço de leitura e nem desafiam os valores do consumidor. PAES, José Paulo, op. cit., 1990, p. 25-26.
} 
ções Amarela e Máscara Negra, de romances policiais. Compostas só de obras traduzidas, principalmente do inglês e do francês, essas coleções assinalam os primórdios da invasão do best-seller estrangeiro, facilitada e estimulada pela ausência de similares nacionais. ${ }^{5}$

Mesmo considerando-a rarefeita, Paes fez um levantamento sumário da literatura voltada ao grande público com escritores considerados sucesso de vendas no Brasil entre os anos 1920 e 1940. Dividiu-os entre quem fez kitsch literário ao atuar no humor, crônica, narrativa histórica e sentimentalismo (como Humberto de Campos, Benjamin Costallat e Paulo Setúbal) e os que atuaram nos gêneros clássicos de entretenimento como policial (Medeiros e Albuquerque, Jerônimo Monteiro e Luís Lopes Coelho), ficção científica (Afonso Schmidt, Rodolfo Teófilo, Fausto Cunha, André Carneiro), aventuras (Menotti Del Picchia) e romance sentimental (Maria José Dupré, José Mauro de Vasconcelos). Diante do quadro rarefeito, Paes conclamava os intelectuais e escritores para outra urgente tarefa:

Talvez à mesma miopia [da violência da crítica contra José Mauro] se deva não ter sido feito até agora um levantamento de nossa ainda paupérrima, mas nem por isso nula, literatura de entretenimento. Enquanto não for feito, a meia dúzia de autores aqui mencionados vale como lembrete de um território ainda à espera de cartógrafos. ${ }^{6}$

A quantidade do inventário levava o ensaísta a procurar entender, para além da literatura infantil popularizada por Lobato, "qual a razão da pobreza ou, melhor dizendo, da quase inexistência de uma literatura brasileira de entretenimento?" Paes se perguntava: se o Brasil tinha uma literatura erudita de grande porte, um farto material folclórico e uma capacidade de criar cultura de massa expressa nas telenovelas, o que teria acontecido? A primeira razão que levantou é sociológica, relativa ao polo consumidor: no Brasil, a cultura de massa audiovisual (cinema, rádio e TV) chegou junto do livro, roubando o seu público ao propiciar entretenimento com pouco esforço intelectual para a população, em sua maioria analfabeta. Simultaneamente, o desenvolvimento tardio da indústria editorial, datado dos anos 1930, priorizava a tradução de livros populares estrangeiros ao invés da produção local. Sem condições de se profissionalizar, no Brasil, os homens de letras se tornavam literatos, desprezando o entretenimento em busca de glórias entre os pares.

PAES, José Paulo, op. cit., 1990, p. 33-34.

6 PAES, José Paulo, op. cit., 1990, p. 35. 
Ao considerar a centralidade dos anos 1930, Paes valeu-se de interpretações já existentes sobre a cultura letrada que também abordam os gêneros para o grande público. Em dois estudos, Sérgio Miceli enfocou os intelectuais, tratando das parcas possibilidades de autonomia que tinham os "anatolianos" no início do século XX e, na década de 1930, a substituição de importações de livros após a crise de 1929 e o aumento do público leitor das classes médias, os quais possibilitaram a expansão do mercado editorial - capitaneada pelos "gêneros menores" - e a emergência do "romancista profissional".7 Nessa linha, estudos posteriores também apontam os anos 1930 como um período importante para a formação da indústria do livro e para a criação de postos de trabalho intelectual, seja tomando como fio condutor o conjunto da cultura popular de massa ${ }^{8}$ ou do mercado editorial, ${ }^{9}$ seja a trajetória particular dos agentes ligados às editoras de grande porte como José Olympio, Lobato e Octales (Companhia Editora Nacional), e Bertaso (Globo). ${ }^{10}$

Essa perspectiva precisa ser matizada pela recente bibliografia que mostra como as narrativas de ficção voltadas ao grande público já circulavam e/ou eram produzidas por brasileiros nos centros urbanos do país desde o século XIX e início do XX, em gêneros como folhetim, romance de

\footnotetext{
7 MICELI, Sérgio. Poder, sexo e letras na República Velha (estudo clínico dos anatolianos) e Intelectuais e classe dirigente no Brasil (1920-1945) In: Idem. Intelectuais à brasileira. São Paulo: Companhia das Letras, 2001. O autor nota que tal emergência ocorreu num período de crescente influência da cultura norte-americana no país.

8 Ortiz data na década de 1930 o início da formação de uma cultura popular de massa no Brasil, o que não se confunde com a realidade concreta dos meios de comunicação, localmente existente desde o início do século XX, mas depende da reestruturação social a partir da emergência de uma sociedade urbano-industrial, processo que coincidiu com a integração dessas mídias em nível nacional. No meio do XX, ela ainda seria incipiente e precária, adquirindo plena vigência a partir da década de 1960 por esforços dos governos militares. Para o autor, o mesmo vale para a cultura letrada e para o mercado editorial, até os anos 1930 sem nítida distinção entre campo ampliado e restrito, como ocorre na França desde o XIX. Aqui o autor segue e vale-se dos estudos de Miceli e Hallewell. ORTIZ, Renato. A moderna tradição brasileira. São Paulo: Brasiliense, 1988, p. 25-37. As teses são retomadas dez anos depois num resumo escrito pelo autor em Sociedade e cultura. In: SACHS, Ignacy et alii. Brasil: um século de transformações. São Paulo: Companhia das Letras, 2001, p. 186-209.

9 HALLEWELL, Laurence. O livro no Brasil. São Paulo: Edusp, 2005.

${ }^{10}$ KOSHIYAMA, Alice. Monteiro Lobato: intelectual, empresário, editor. São Paulo: Edusp/ComArte, 2006; BEDA, Ephraim de Figueiredo. Octalles Marcondes Ferreira: formação e atuação do editor. Dissertação de mestrado, ECA-USP, São Paulo, 1987; TORRESINI, Elisabeh Rochadel. Editora Globo: uma aventura editorial nos anos 30 e 40. São Paulo: Edusp, ComArte; Porto Alegre: EdUFRGS, 1999; AMORIM, Sônia Maria. Em busca de tempo perdido: edição de literatura traduzida pela Editora Globo (1930-1950). São Paulo: Edusp/ComArte; Porto Alegre: EdUFRGS, 1999; SORÁ, Gustavo. Brasilianas. José Olympio e a gênese do mercado editorial brasileiro. São Paulo: Edusp/ComArte, 2010.
} 
sensação e "para homens", especulativos (fantasia, ficção científica e horror), jornalísticos (reportagem e crônicas), humorísticos e policiais. ${ }^{11}$ Tal produção dialogava e se imbricava com a literatura hoje considerada erudita. Tais estudos permitem abordar de maneira complexa e multifacetada tal ficção e questionar a periodização que coloca os anos 1930 como marco fundador. Porém, longe de esvaziar, tal cuidado reforça a necessidade de considerar as especificidades dessa década, na qual transformações editoriais repercutiram nos gêneros de grande consumo, o que foi percebido como novidade na época. Essa percepção será o foco deste artigo.

Pretendemos analisar, entre 1930 e início dos anos 1940, a repercussão dos gêneros ficcionais destinados ao grande público entre escritores, editores e intelectuais brasileiros, cujas opiniões expressaram-se através de jornais, revistas e outros periódicos publicados em São Paulo e no Rio de Janeiro. Os rumos do mercado editorial, ao possibilitar a ampliação da produção e a distribuição nacional do livro, colocava uma questão crucial para os envolvidos na cultura letrada no Brasil: como lidar com “a existência de um público de leitores cujas preferências e escolhas em matéria de leitura são um tanto independentes dos juízos externados pelos detentores da autoridade intelectual" ?12

\footnotetext{
${ }^{11}$ Alguns autores têm se dedicado a analisar a história dos gêneros destinados ao grande público numa temporalidade mais larga, desde o século XIX, passando pela Primeira República e chegando aos anos 1930 e 1940. Para a relação do jornalismo com a literatura, ver BARBOSA, Marialva. História cultural da imprensa: Brasil - 1900-2000. Rio de Janeiro: Mauad X, 2007. BULHÕES, Marcelo. Jornalismo e literatura em convergência. São Paulo: Ática, 2007; COSTA, Cristiane. Pena de aluguel: Escritores jornalistas no Brasil - 1904 a 2004. São Paulo: Companhia das Letras, 2005. Sobre a literatura de fantasia, horror e ficção científica, ver CAUSO, Roberto de Sousa. Fição científica, fantasia e horror no Brasil (1875-1950). Belo Horizonte: UFMG, 2003. O humor foi estudado por SALIBA, Elias Thomé. Raízes do riso. São Paulo: Companhia das Letras, 2002. Já os gêneros de "sensação" foram objeto de EL FAR, Alessandra. Páginas de sensação: literatura popular e pornográfica no Rio de Janeiro (1870-1924). São Paulo: Companhia das Letras, 2004. O folhetim foi estudado por MEYER, Marlise. Folhetim: Uma história. São Paulo: Companhia das Letras, 1996. A literatura policial foi objeto de REIMÃO, Sandra. literatura policial brasileira. Rio de Janeiro: Zahar, 2005 e ALBUQUERQUE, Paulo. O mundo emocionante do romance policial. Rio de Janeiro: Francisco Alves, 1979, cap. 15.

${ }^{12}$ MICELI, Sérgio. Intelectuais e classe dirigente no Brasil (1920-1945). In: Idem. Intelectuais à brasileira. São Paulo: Companhia das Letras, 2001, p. 155.
} 


\section{Novo surto de ficção popular nos anos 1930}

Uma rápida olhada para as estatísticas sobre potenciais leitores na população brasileira dos censos de 1920 e 1940 pode ajudar a entender a questão:

Grau de instrução por faixa etária segundo o censo de 1920 - Brasil

\begin{tabular}{|c|c|c|}
\hline Idade & Sabe ler e escrever & Não sabe ler e escrever \\
\hline Até 6 anos & 38.659 & 6.457 .647 \\
\hline De 7 a 14 anos & 1.299 .131 & 5.282 .836 \\
\hline De 15 e mais anos & 6.155 .567 & 11.401 .715 \\
\hline Total & 7.493 .357 & 23.143 .248 \\
\hline
\end{tabular}

Fonte: Estado da população. Tabela XIII: Recenseamento de 1920 - População do Brasil e das suas unidades políticas, segundo o grau de instrução e idade. In: IBGE, 2003.

Grau de instrução por faixa etária segundo o censo de 1940 - Brasil

\begin{tabular}{|l|r|r|r|}
\hline \multicolumn{1}{|c|}{ Idade } & $\begin{array}{c}\text { Sabe ler } \mathbf{c} \\
\text { escrever }\end{array}$ & $\begin{array}{c}\text { Não sabe ler e } \\
\text { escrever }\end{array}$ & $\begin{array}{c}\text { Instrução não } \\
\text { declarada }\end{array}$ \\
\hline 0 a 9 anos & 794.474 & 4.842 .658 & 121.684 \\
\hline 10 a 19 anos & 4.131 .939 & 5.603 .058 & 37.006 \\
\hline 20 a 29 anos & 3.310 .266 & 3.842 .551 & 16.908 \\
\hline 30 a 39 anos & 2.224 .939 & 2.664 .606 & 12.137 \\
\hline 40 a 49 anos & 1.433 .281 & 1.999 .760 & 8.686 \\
\hline 50 a 59 anos & 814.803 & 1.224 .917 & 5.187 \\
\hline 60 a 69 anos & 390.240 & 682.898 & 7.001 \\
\hline 70 a 79 anos & 139.715 & 286.538 & 1.823 \\
\hline 80 ou mais & 36.933 & 134.071 & 208.570 \\
\hline Não declarada & 16.015 & 14.433 & 707 \\
\hline \multicolumn{1}{|c|}{ Total } & 13.292 .605 & 21.295 .490 & \\
\hline
\end{tabular}

Fonte: Estado da população. Tabela II - População do Brasil, na data do recenseamento geral de 1940. 1. Distribuição, por sexo e grupos de idade, segundo os principais caracteres individuais: d) instrução, ambos os sexos. In: IBGE, 2003. 
Os quadros acima permitem ver que, em 1940, o número de analfabetos continuou alto em todas as idades, compondo quase dois terços da população, mas diminuiu em relação ao censo anterior. A proporção entre leitores e não leitores também se alterou, tendo em vista que o número absoluto dos que sabem ler e escrever quase dobrou. Na categorização etária, chama a atenção como o aumento se concentrou no público juvenil e de jovens adultos, cujos valores somados quase totalizam os leitores de 1920. Não foi casual que uma parte das obras de ficção das principais editoras se direcionava a essa faixa etária e articulistas se entusiasmavam com as perspectivas de mudança social abertas por uma geração de jovens leitores. Ao comentar a desproporção entre as obras direcionadas ao público infanto-juvenil e aos adultos nas tiragens da Companhia Editora Nacional, um articulista da Folha da Manhã conclui:

Em face do Brasil de ontem, analfabeto e cru, do Brasil de ontem que é representado no hoje por homens e mulheres que em toda sua vida não leram um livro, representado pelas nossas classes dirigentes, onde a elite cultural é quase nula, surge o Brasil de hoje e de amanhã, representado pelos jovens, pelas moças e crianças que leem, que se interessam pelas coisas do pensamento e que amanhã varrerão na indústria, no comércio, na política e nas profissões liberais esses fósseis incultos de hoje que são a vergonha de nossa terra e o peso morto que impede o seu progresso..$^{13}$

A força messiânica atribuída à leitura do povo em geral e dos moços em especial, ressaltando sua força de mudança e seu papel para o progresso do país num futuro próximo, foi tônica nos jornais. Tais anseios vão ao encontro da hipótese de Sérgio Miceli, para quem tal público se formou por causa das mudanças ocorridas no sistema de ensino e na expansão dos setores médios da população.

A questão do ensino pode ser remontada às reformas geradas por conta do entusiasmo com a educação nos anos 1920, vista como solução para as mazelas políticas, sociais e culturais do país. O surgimento dos educadores profissionais ensejou aumento de publicações de livros e revistas pedagógicas, e o aumento dos congressos, inquéritos e conferências sobre problemas educacionais. Além da fundação de uma Associação Brasileira de Educação em 1924, todo o clima de debate repercute na ação estatal: em nível federal, criaram-se as primeiras universidades brasileiras, a do Rio de Janeiro (1920) e de Minas Gerais (1927), e se reorganizou o ensino secundário e superior

\footnotetext{
${ }^{13}$ VELHO, Mathias Porto. O mundo dos livros. Folha da Manhã, 01/03/1934, p. 5.
} 
(1925) e técnico-profissional (1926). Em nível estadual, responsável pelo ensino primário e normal, foi marcante a onda de reformas que se espalhou pelo país durante essa década, que "procedem à implantação ou reorganização da administração escolar, bem como ao uso de instrumentos de planejamento, como os recenseamentos escolares. Dá-se novo passo no sentido de ampliação da rede e da clientela escolares". ${ }^{14}$

Nos anos 1930, a centralização federal orientou as mudanças educacionais. Foi criado o Ministério da Educação e Saúde Pública, cujo cargo foi ocupado por Francisco Campos que, em 1931, baixou uma série de decretos no sentido de reformar o ensino superior, comercial e o secundário. Diminuiu de sete para cinco os anos necessários para certificação secundária para quem não seguisse curso superior, além de reformular o currículo e aumentar o número de matrículas. Ao mesmo tempo em que se criaram novos cursos técnicos e superiores ${ }^{15}$ surgiram outras universidades brasileiras, como a Universidade de São Paulo em 1934. Esse movimento de expansão no ensino também movimentou o mercado editorial de livros didáticos e pedagógicos para todos os níveis e áreas.

Outro processo que contribuiu para a ampliação do público leitor se deu

por força das mudanças ocorridas na hierarquia de ocupações do setor terciário dos principais centros urbanos, impulsionado pelo aumento dos postos técnicos e de gestão nos setores público e privado e pela expansão considerável do número de portadores de diplomas superiores na área das profissões liberais. ${ }^{16}$

Um depoimento de Jorge Amado, baseado em sua experiência de trabalho em uma editora no Rio, ia no mesmo sentido. Além de considerar a questão do empréstimo ao estimar cinco a dez leitores para cada exemplar vendido nas livrarias, uma campanha de livros precisa considerar o perfil dos compradores:

\footnotetext{
${ }^{14}$ O parágrafo baseia-se em NAGLE, Jorge. A educação na Primeira República. In: FAUSTO, Boris (org.). História geral da civilização brasileira - o Brasil republicano, tomo 3, v. 2. Rio de Janeiro/São Paulo: Difel, 1978, p. 264. Associadas a nomes que se tornariam referência no pensamento educacional brasileiro, as principais reformas foram: Sampaio Dória (São Paulo, 1920), Lourenço Filho (Ceará, 1923), Anísio Teixeira (Bahia, 1925), Francisco Campos (Minas Gerais, 1927), Fernando de Azevedo (Distrito Federal, 1928), Carneiro Leão (Pernambuco, 1929) e Lourenço Filho (São Paulo, 1930).

15 SAVIANI, Demerval. História das ideias pedagógicas no Brasil. Rio de Janeiro: Bertrand Brasil, 2008, p. 195-8. A reforma Capanema de 1942 aprofundou o processo ao dividir o secundário em ginásio (quatro anos) e colégio (três anos), possibilitando diplomas em graus intermediários.

${ }^{16}$ MICELI, Sérgio. Intelectuais e classe dirigente no Brasil (1920-1945). In: Idem. Intelectuais à brasileira. São Paulo: Companhia das Letras, 2001, p. 155.
} 
É preciso compreender que o público brasileiro é em geral um público pobre. Os ricos não leem, têm mais o que fazer. O intelectual, que é a classe mais interessada, não compra o livro. Primeiro porque não tem dinheiro suficiente, segundo porque recebe em geral o livro de graça. Compra o livro a pequena burguesia composta em geral de estudantes, semi-intelectuais, rapazes e moças que leem por luxo e não por necessidade (ler no Brasil só agora começa a deixar de ser luxo). ${ }^{17}$

Para Miceli, esta mudança não foi apenas quantitativa, mas repercutiu no tipo de gosto, pois

o primeiro posto da literatura de ficção - e nessa categoria, a predominância dos romances de amor, de histórias policiais e de livros de aventuras - deve-se em ampla medida à expansão da parcela de leitores recrutada nas novas camadas médias, que redundou no aumento da demanda por obras de mero entretenimento. ${ }^{18}$

A demanda pelos gêneros citados coincidiu com um contexto de retração das importações, em drástica queda com a crise de 1929 e subsequente desvalorização da moeda (o mil-réis). Isso possibilitou, nos anos 1930, o investimento editorial em um mercado nacional até então dominado por livros portugueses e franceses: "pela primeira vez desde o início do século XIX, o livro brasileiro - vendido a mais ou menos $6 \$ 000$ para um romance normal - tornava-se competitivo em seu próprio mercado nacional". ${ }^{19}$ Esse cenário ensejou o surgimento de inúmeras editoras e o estabelecimento das maiores empresas do país nesse ramo, como a José Olímpio (São Paulo e Rio) e a seção editora da Livraria do Globo (Porto Alegre), que ombrearam a Companhia Editora Nacional (São Paulo), fundada em meados dos anos 1920.

A fórmula da qual as editoras se valeram para atingir o público em expansão foram as coleções. Implicavam uma segmentação de mercado ao editar, em maior escala e por menor preço, livros para leitores especiais. No Brasil dos anos 1930

as coleções foram expressões materiais da política de popularização da leitura, e também da especialização profissional e da divisão do trabalho no campo editorial, uma vez que demandava políticas de acervo editoriais e reforçava o papel estratégico do editor, que se tornava um especialista, responsável tanto pela definição de um perfil, ao decidir

\footnotetext{
${ }^{17}$ AMADO, Jorge. A situação do livro e do escritor (entrevista a José Lins do Rego). Folha da Manhã , 24/12/1935, p. 6.

${ }^{18}$ MICELI, Sérgio. Intelectuais e classe dirigente no Brasil (1920-1945). In: Idem. Intelectuais à brasileira. São Paulo: Companhia das Letras, 2001, p. 155.

${ }^{19}$ HALLEWELL, Laurence. O livro no Brasil. São Paulo: Edusp, 2005, p. 398.
} 
o critério de reunião, de seleção das obras de uma coleção - seja por compilações de autores sobre um mesmo tema, em obras de um mesmo gênero ou destinação reunidas em série ou que compartilham traços materiais uniformes, como cor, logotipo, tamanho -, quanto pelo direcionamento da atuação da editora para determinadas faixas do mercado livreiro. ${ }^{20}$

O fato de nas coleções de ficção constar principalmente livros traduzidos era um componente a mais na redução de custos do negócio, sobretudo para novos editores. Apesar da despesa com a tradução, que abriu uma frente de remuneração para escritores e intelectuais, ${ }^{21}$ para o editor brasileiro

o editor estrangeiro, na verdade, já deu conta de "quase" tudo: escolheu autor e obra, definiu formato, tipologia, configuração visual do livro, sem contar que já correu o risco de editar algo inédito, testando seu feeling editorial. O livro estrangeiro chega aqui com o aval do editor e do público originais. O editor nacional, muitas vezes, se apropria desse trabalho, cuidando apenas das fases mais industriais do processo. ${ }^{22}$

Essas tendências editoriais do início dos anos 1930 podem ser vislumbradas a partir dos dados das tiragens, em 1933, da maior editora do país, a Companhia Editora Nacional, sediada em São Paulo:

\footnotetext{
${ }^{20}$ O parágrafo e a citação estão baseados em DUTRA, Eliana Freitas. Mediação intelectual e percursos da cultura no Brasil dos anos 1930: o caso da coleção Brasiliana e da Cia Editora Nacional. In: RODRIGUES, Helenice $\mathcal{E}$ KOHLER, Heliane (org.). Travessias e cruzamentos culturais: a mobilidade em questão. Rio de Janeiro: FGV, 2008, p. 154-5.

${ }^{21}$ Eram inúmeras as reclamações contra as traduções dos romances populares estrangeiros na imprensa, o que era considerado um empecilho à difusão de livros no país. Tanto que, para se distinguir, a Companhia Editora Nacional passou a ressaltar o nome dos tradutores nas propagandas, o que agregava valor ao produto: "chamamos a atenção para o nome dos tradutores da nova fase desta coleção". Entre os nomes estavam Monteiro Lobato, Gustavo Barroso, Manuel Bandeira, Godofredo Rangel (Folha da Manhã, 30/05/1935, p. 11).

${ }^{22}$ AMORIM, Sônia Maria. Em busca de tempo perdido: edição de literatura traduzida pela Editora Globo (1930-1950). São Paulo: Edusp, ComArte; Porto Alegre: Editora UFRGS, 1999, p 71.
} 
Tiragens dos exemplares da Companhia Editora Nacional (jan.-nov. de 1933)

\begin{tabular}{|l|r|r|}
\hline \multicolumn{1}{|c|}{ Discriminação } & Tiragem & \multicolumn{1}{c|}{$\mathbf{~}$} \\
\hline Livros didáticos & 340.000 & 28,3 \\
\hline Atualidades pedagógicas e iniciação científica & 39.200 & 3,3 \\
\hline Brasiliana & 67.000 & 5,6 \\
\hline Literatura infantil & 92.500 & 7,7 \\
\hline Coleção Paratodos & 107.000 & 8,9 \\
\hline Coleção Terramarear & 230.000 & 19,1 \\
\hline Nova Biblioteca das Moças & 107.000 & 8,9 \\
\hline Contos, crônicas, romances e ensaios & 59.000 & 4,9 \\
\hline Regionalismo e humorismo & 27.000 & 2,2 \\
\hline Poesias & 23.100 & 1,9 \\
\hline Educativos & 53.000 & 4,4 \\
\hline Viagens & 6.000 & 0,5 \\
\hline Medicina & 5.200 & 0,4 \\
\hline Direito & 3.000 & 0,2 \\
\hline Comércio & 8.700 & 0,7 \\
\hline Obras diversas & 34.200 & 2,8 \\
\hline Total & $\mathbf{1 . 2 0 1 . 9 0 0}$ & $\mathbf{1 0 0 , 0 0}$ \\
\hline
\end{tabular}

Fonte dos dados: VELHO, Mathias Porto. O mundo dos livros. Folha da Manhã, 01/03/1934, p. 5.

Percebemos que a atuação da editora concentrava-se no ramo educacional (livros didáticos, atualidades pedagógicas e educativos - 431.200 exemplares) e na literatura de ficção popular (literatura infantil, coleção Paratodos, coleção Terramarear e Nova Biblioteca das Moças - 536.500 exemplares). ${ }^{23}$ Integrando a Biblioteca Pedagógica Brasileira junto com os didáticos e a Brasiliana, a literatura infantil estava sob a responsabilidade de Monteiro Lobato, que não só produzia livros (Reinações de Narizinho, O saci, Novas reinações de Narizinho, As

\footnotetext{
${ }^{23}$ No ano seguinte, o selo desta editora foi reservado a esses ramos de sucesso, sendo os outros segmentos priorizados pela Civilização Brasileira, adquirida em 1932. HALLEWELL, Laurence. O livro no Brasil. São Paulo: Edusp, 2005, p. 355.
} 
caçadas de Pedrinho), como adaptava histórias (como Aventuras de Hans Staden) e realizava traduções (Alice no País das Maravilhas, Contos de Andersen, Pinóquio). ${ }^{24}$

Já nas outras três coleções de ficção com maior tiragem eram publicadas traduções de autores estrangeiros, sobretudo de língua inglesa, nos gêneros aventura, mistério, policial, histórico e sentimental. A Paratodos contemplava todos esses gêneros e, como o próprio nome sugere, destinava-se ao maior público possível. Dentre os autores mais publicados nesse ano de 1933 estavam Edgard Wallace, Rafael Sabatini, baronesa Orczy e Conan Doyle, contando ainda com alguns títulos de Jack London, Robert Louis Steveson, Sax Rohmer e outros. As outras duas coleções, apesar de "servirem também ao homem maduro e culto", ${ }^{25}$ eram segmentadas ao público jovem: a Terramarear publicava sobretudo aventuras destinadas aos adolescentes, com obras de Kipling (Mogli), Edgar Burroughs (série Tarzan), Steveson ( $A$ ilha do tesouro), Jack London (Caninos brancos), Mark Twain (O príncipe e o pobre) etc. Já a Nova Biblioteca das Moças priorizava o gênero sentimental, visando público jovem feminino, sendo Concordia Merrel a autora mais publicada até o fim de 1933 (Casada por dinheiro, A maltrapilha, O homem sem piedade, Casamento por vingança, Adão e algumas Evas). ${ }^{26}$ Em 1934, a Nacional lançou a série Negra, com romances policiais e de mistérios. Dirigida pelo escritor Moacir de Abreu, o principal autor foi Edgard Wallace (O homem do hotel Carlton, $O$ calendário, $O$ homem de borracha), seguido de Van Dine ( $O$ crime do escaravelho, $O$ crime do dragão), contando também com Conan Doyle ( $O$ doutor Negro). ${ }^{27}$

Outra das maiores editoras do país que se valeu dessa ficção com objetivos comerciais foi a Globo de Porto Alegre, dirigida por Henrique Bertaso e com apoio de Érico Veríssimo: “a maior parte dos primeiros sucessos da Globo originou-se da mania anglo-americana de histórias policiais, que sua 'Coleção Amarela' trouxe, em grande parte, para o Brasil". ${ }^{28}$ Carro-chefe da

\footnotetext{
${ }^{24}$ Cf. Catálogo da Companhia Editora Nacional. Folha da Manhã, 22/10/1933, p. VII, suplemento. Sobre a literatura infantil no período, ver SOARES, Gabriela Pellegrino. Semear horizontes: uma história da formação de leitores na Argentina e no Brasil, 1915-1954. Belo Horizonte: Editora UFMG, 2007.

${ }^{25}$ VELHO, Mathias Porto. O mundo dos livros. Folha da Manhã, 01/03/1934, p. 5.

${ }^{26}$ Os autores e títulos referentes às três coleções constam do Catálogo... Folha da Manhã, 22/10/1933, suplemento, p. VII. Até 1957, os títulos publicados pelas coleções foram: Paratodos (60), Terramarear (82), Biblioteca das Moças (168). Cf. DUTRA, Eliana Freitas. Mediação intelectual e percursos da cultura no Brasil dos anos 1930: o caso da coleção Brasiliana e da Cia Editora Nacional. In: RODRIGUES, Helenice $\mathcal{E}$ KOHLER, Heliane (org.). Travessias e cruzamentos culturais: a mobilidade em questão. Rio de Janeiro: FGV, 2008, p. 155.

${ }^{27}$ As propagandas da série Negra foram publicadas na Folha da Manhã, 08/08/1934, p. 11.

${ }^{28}$ HALLEWELL, Laurence. O livro no Brasil. São Paulo: Edusp, 2005, p. 398.
} 
editora na década de 1930, esta coleção publicou, a partir de 1932, 156 títulos de autores como Edgar Wallace, Conan Doyle e Agatha Christie. Outras coleções da editora Globo voltadas aos consumidores dos gêneros acima citados ${ }^{29}$ foram a Verde (1929, romances sentimentais), Globo (1933, era o equivalente da Paratodos, publicando romances de aventuras, sentimentais e policiais), Universo (1931, viagens e aventuras), parte da famosa coleção Nobel (1933), e as curtas coleções Clube do Crime e Espionagem (1931-32). ${ }^{30}$ Tal literatura compunha uma expressiva parte dos títulos lançados pela editora gaúcha:

A produção da seção editora [da Globo]: 1931-1937

\begin{tabular}{|l|c|c|}
\hline \multicolumn{1}{|c|}{ Gênero } & Frequência & $\mathbf{0}$ \\
\hline Literatura estrangeira & 213 & 25,4 \\
\hline Ciências humanas, sociais e econômicas & 146 & 17,4 \\
\hline Ciências exatas e naturais & 104 & 12,4 \\
\hline Dicionários, gramáticas e teoria literária & 96 & 11,5 \\
\hline Literatura rio-grandense & 78 & 9,3 \\
\hline Direito e legislação & 35 & 4,2 \\
\hline Lazer e esportes & 10 & 1,2 \\
\hline Culinária e trabalhos manuais & 11 & 1,3 \\
\hline Literatura brasileira & 8 & 0,9 \\
\hline Almanaques e memoriais & 8 & 0,9 \\
\hline Outros & 43 & 5,1 \\
\hline Não registrados & 40 & 4,7 \\
\hline Não classificados & 48 & 5,7 \\
\hline Total & $\mathbf{8 4 0}$ & $\mathbf{1 0 0}$ \\
\hline
\end{tabular}

Fonte: Livro de registros da Editora Globo. In: TORESINI, op. cit., 1999, p. $78 .^{31}$

\footnotetext{
29 “O período de 1930 a 1950, por sua vez, pode ser subdividido, segundo os 'níveis' de literatura editados: nos anos 30, predomina uma literatura mais popular, de consumo imediato, chamada literatura de entretenimento por José Paulo Paes, para evitar juízos de valor. Nos anos 40, há uma preocupação visível em se editar uma literatura mais elaborada, embora a 'argamassa popularesca', para usar uma expressão de Érico Veríssimo, continue predominando." AMORIM, Sônia Maria. Em busca de tempo perdido: edição de literatura traduzida pela Editora Globo (1930-1950). São Paulo: Edusp, ComArte; Porto Alegre: Editora UFRGS, 1999, p. 66.

${ }^{30}$ Detalhes sobre as coleções podem ser lidas em AMORIM, Sônia Maria, op. cit., 1999, p. 72-106. As datas mencionadas são relativas ao início das coleções. Algumas duraram pouco tempo enquanto outras perduraram por mais de uma década. Sobre a coleção Amarela, ver também ALBUQUERQUE, Paulo. O mundo emocionante do romance policial. Rio de Janeiro: Francisco Alves, 1979, apêndice 4.

${ }^{31}$ TORRESINI, Elisabeh Rochadel. Editora Globo: uma aventura editorial nos anos 30 e 40. São Paulo: Edusp, ComArte; Porto Alegre: Editora UFRGS, 1999.
} 
Sobre os títulos de literatura estrangeira lançados pela Globo, que representavam um quarto da sua produção no período,

pode-se afirmar que cerca de 75\% dos títulos de literatura traduzida pertencem à chamada literatura de massa-popular-amena-de entretenimento, contra 25\% de literatura mais elaborada. Se radicalizarmos e considerarmos autores como Somerset Maugham, James Hilton e Charles Morgan como produtores de obras não pertencentes à literatura culta-erudita-de proposta, a diferença entre as percentagens se acentua: 85\% para 15\%. A proporção fica um tanto assustadora: para um título de literatura "culta" foram editados seis de literatura de massa. Em termos de autores a proporção também assusta: um para cinco. ${ }^{32}$

Tais tendências permanecem além do final da década, visto que o destaque dado a esse tipo de literatura se manteve nacionalmente:

Dentre todos os gêneros editados de 1938 a 1943 a literatura de ficção ocupa o primeiro posto em virtude dos elevados índices de venda que alcançam os chamados "gêneros menores", isto é, os romances das coleções "menina-moça", os policiais e os livros de aventuras, aos quais se podem acrescentar as biografias romanceadas, gêneros que detêm a sétima posição no ranking, e mais uma parcela das obras infantis. Quando se considera o conjunto dos gêneros literários (ensaio, crítica, história literária, poesia, teatro etc.), a produção nessa área chega a cobrir 38\% dos títulos.

Um terço dos romances - 52 títulos entre 156 publicados em 1942, sendo 62\% de traduções e 38\% de obras de autores nacionais - foi veiculado pelas diversas coleções endereçadas ao público feminino (Biblioteca das Moças, da Companhia Editora Nacional; Menina e Moça, da José Olímpio; Biblioteca das Senhorinhas, da Empresa Editora Brasileira; Romance para Moças, da Anchieta). ${ }^{33}$

Alguns registros da época chegam ao mesmo diagnóstico ao tratar da difusão desses gêneros na sociedade. Ao criticar a "literatura nociva" (policial) entre adultos e principalmente entre jovens estudantes do ensino secundário, um articulista comentou que "nos bondes, trens, ônibus, jardins públicos e, até nas aulas, devoram os meninos tão nocivas páginas". ${ }^{4}$ A leitura desses gêneros não ocorria só nas ruas como também em um espaço destinado à leitura, as bibliotecas. Em São Paulo, ao ressaltar na Folha da Manhã a importância da coleção Terramarear, Hermes Lima mencionou sua

\footnotetext{
32 AMORIM, Sônia Maria, op. cit., 1999, p. 67-68. A autora toma o cuidado de não tornar absolutas as noções de literatura erudita e de massa, considerando que existem gradações entre os extremos.

${ }^{3}$ MICELI, Sérgio, op. cit., 2001b, p. 154.

${ }^{34}$ Literatura nociva. Gazeta de Notícias, 11/05/1937, p. 3.
} 
frequência às bibliotecas públicas da cidade e, após fazer "uma pequena estatística para esclarecer melhor o assunto, tomando por base a média de leitura de alguns dias", concluiu que os rapazes "procuram de preferência os livros de aventura, os dramas que exaltam a imaginação, as narrativas capazes de lhe encherem a alma com o eco de façanhas e lutas". ${ }^{35}$ A mesma tendência foi detectada anos depois em relação à Biblioteca Nacional no Rio. Segundo a Gazeta de Notícias, além daqueles que iam passar o tempo e achar amores novos paquerando as funcionárias, havia os que liam:

...quase frequentada exclusivamente por intelectuais e estudantes, a Biblioteca da Praça Marechal Floriano mostra um índice relativamente baixo de assuntos consultados. A preferência é pelos livros didáticos, as histórias policiais e os romances populares. Obras verdadeiramente culturais, poucas saem dos armários para consultas. E quando acontece de saírem, via de regra, voltam logo, imediatamente, aos seus lugares, pois saíram, apenas, para uma ligeira consulta. Para desfazer alguma dúvida ou decidir qualquer aposta. ${ }^{36}$

A mesma conclusão vinha das opiniões dos comerciantes diretos de tal literatura. Do meio da década de 1930 em diante, os rápidos inquéritos de jornal apontavam as preferências dos leitores na opinião dos comerciantes de livros. Num destes, em 1938, um jornalista do Diário Carioca percorreu a rua do Ouvidor, no Rio, para entrevistar os livreiros. No primeiro, indagou sobre as preferências dos leitores e obteve como resposta: "a grande maioria está com a literatura de emoções e aventuras, gênero far-west e policial". Na loja seguinte, uma resposta semelhante: "vende-se muita literatura policial, cujos lucros não satisfazem dado o preço dos exemplares, em geral confeccionados em traduções apressadas". A mesma resposta foi dada pelos vendedores de livros usados, os belquiores (sebos), onde, além dos leitores, outros livreiros compravam livros para revender mais caro. Sobre as preferências do público, saíam principalmente "livros de aventuras e as histórias de Delly e Ardel para moças", além de "literatura pornográfica, revistas ilustradas e folhetos 'de cordel', conhecidos sempre por dois nomes bombásticos: 'Sete dias na Groenlândia ou O esquimó malvado', 'A virgem maldita ou Memórias da filha do carrasco' e outros desta espécie". ${ }^{37}$

\footnotetext{
${ }^{35}$ LIMA, Hermes. Terra-mar-e-ar. Folha da Manhã, 29/04/1933, p. 6.

36 Biblioteca "para inglês ver". Gazeta de Notícias, 19/06/1941, p. 6.

37 Que lê o carioca. Diário Carioca, 23/03/1938, p. 3 e 12.
} 
Os editores tinham uma percepção análoga a partir do seu ofício, o que pode ser observado através das respostas dos grandes, médios e pequenos editores do Rio, e alguns de São Paulo, ${ }^{38}$ a um inquérito publicado em 1938 pelo Anuário Brasileiro de Literatura, da Pongetti. Na pergunta sobre as tendências de leitura do público na década de 1930 destacam-se duas percepções: a variedade e inconstância de gosto e a popularidade dos gêneros veiculados. No primeiro caso, seis editores consideram negativamente uma ausência de padrão de gosto. Como apontam os donos da Athena e da Minerva, a mudança repentina de preferências torna difícil definir as tendências, visto que os leitores leem de tudo e retomam gostos antes desprezados. Esta posição é marcada pela necessidade de constância de investimento exigida pelo negócio editorial, evitando altos riscos, como fica explícito na resposta do responsável pelas Edições Cultura Brasileira, Galeão Coutinho:

...podemos verificar as várias tendências do nosso público. Essas tendências são tão caprichosas, que desnorteiam o editor. Os nossos leitores abandonaram hoje, o que ontem preferiam. (...) A grande dificuldade dos editores é acompanhar essas ondulações, numa época em que o livro envelhece de um dia para o outro, como o jornal. ${ }^{39}$

José Olímpio tem a mesma percepção sobre o assunto:

É verdade que a literatura tem um público especial e numeroso, em vista do que tinha há dez anos antes, o que nos levou a contar com verdadeiros "records" de livraria. Não há, porém, um público estável, a que se possa confiar o êxito de um livro, por isso que não é raro termos esgotado um livro fraco e retardado a venda de um livro de mérito. ${ }^{40}$

A inconstância a que se referem esses editores dizia respeito a obras consideradas de alto valor intelectual, pois, na mesma resposta, deixavam transparecer quais eram os livros de vendagem constante, como Galeão Coutinho: "ainda não há no Brasil as várias camadas de leitores com as suas predileções bem marcadas. Há duas camadas: a dos que só leem romances policiais e a dos que leem tudo, inclusive os romances policiais". José Olímpio foi pelo mesmo caminho: "É lamentável dizermos; porém, o gênero policial é o que tem procura certa. Vamos, pois, seguir a tendência, iniciando a nossa série policial, ainda em princípio de 38 ".41 O responsável pela

\footnotetext{
${ }^{38}$ Ver O que se lê no Brasil. Anuário Brasileiro de Literatura, v. 2. Ed. Pongetti, 1938, p. 401-8.

${ }^{39} \mathrm{O}$ que se lê no Brasil. Anuário Brasileiro de Literatura, v. 2. Ed. Pongetti, 1938, p. 402.

${ }^{40} \mathrm{O}$ que se lê no Brasil, op. cit., 1938, p. 401.

${ }^{41} \mathrm{O}$ que se lê no Brasil, op. cit., 1938, p. 402 e 401.
} 
Civilização Brasileira vislumbrava de maneira mais ampla a segmentação do mercado literário:

Há "vários" públicos, alguns já existentes no Brasil há muito tempo, outros, que só agora vêm se formando. Por exemplo: o público que prefere, nessa mesma ordem decrescente, o romance - o conto - a crônica - a poesia é antigo em nosso país. Atualmente ele se desenvolve, menos no que diz respeito à poesia, que continua cada vez mais sem leitores. Este público nada tem a ver com o vasto e numeroso público de leitores de romances policiais e livros de aventuras, gênero que arrasta talvez a grande maioria dos leitores brasileiros. Há, um outro público, este novo, que só agora aparece e se forma. É o que, nestes dois últimos anos, tem voltado as suas vistas para os chamados "clássicos". Antigamente era uma aventura lançar-se um livro de Platão, por exemplo. Hoje, pelo contrário, os clássicos gregos ou os clássicos latinos são procurados por um público de várias idades que não mais despreza Ésquilo nem Sófocles, preferindo, contudo, aquelas obras onde se note um conteúdo político-filosófico, sem esquecer ainda, o público das biografias, um dos mais numerosos. ${ }^{42}$

Alguns editores chegavam a uma percepção parecida a partir da aceitação ou não de suas próprias coleções. Por exemplo, a Casa Mandarino considerava a literatura feminina o gênero de maior preferência do público tendo em vista que a "tentativa da constituição de uma biblioteca de clássicos não teve a aceitação que prevíamos, enquanto os romances para moças da nossa 'coleção rosa', veem obtendo uma vendagem admirável". 43 O mesmo respondeu a Companhia Editora Nacional:

O livro de aventuras, a literatura policial, o romance de amor no estilo "flor de laranjeiras", de Delly, continuam a merecer a preferência da maioria do público brasileiro que tem o hábito da leitura. Certo é que se nota na elite apreciadora dos trabalhos de cultura e a grande série "Brasiliana" a mais vasta e completa coleção e sistematização, que se tentou até hoje de estudos brasileiros e que vem de ultrapassar o seu centésimo volume publicado, um animador aumento nestes últimos tempos. Mas ainda é uma minoria. O público, a massa, prefere a literatura de ficção, que distrai sem fazer pensar. ${ }^{44}$

Devido a essa expansão e difusão, os editores procuravam coadunar suas necessidades financeiras com as de legitimação intelectual, como aponta Sérgio Miceli:

\footnotetext{
42 O que se lê no Brasil, op. cit., 1938, p. 403, grifo nosso.

43 O que se lê no Brasil, op. cit., 1938, p. 405.

44 O que se lê no Brasil, op. cit., 1938, p. 407.
} 
Vale a pena chamar a atenção para o modelo de legitimidade cultural que norteia o programa de publicações das principais editoras do período em questão. Tendo que satisfazer às demandas objetivas do público da época e, ao mesmo tempo, veicular a produção crescente das novas categorias de produtores - pensadores políticos, sociólogos, antropólogos, historiadores, folcloristas, educadores - que estavam à frente do processo de diferenciação do campo intelectual, as grandes editoras repartem seus lançamentos entre dois tipos de coleção: as coleções destinadas exclusivamente a difundir os diversos gêneros ficcionais, desde as traduções dos clássicos até as obras de literatura policial, e as coleções de estudos brasileiros, sendo que essa repartição dependia da diversificação a que chegavam os investimentos dos editores e, sobretudo, da autoridade intelectual e do poder de consagração de que dispunham. Enquanto a José Olimpio dispõe da coleção Documentos Brasileiros ao lado das coleções Fogos Cruzados, Menina e Moça, O Romance para Você, a Companhia Editora Nacional desenvolve a coleção Brasiliana junto com as coleções Paratodos, Terramarear, Negra, Biblioteca das Moças, e a Martins, a Biblioteca Histórica Brasileira ao lado da coleção Excelsior. ${ }^{45}$

\section{Percepções sobre o papel dos gêneros populares para a cultura brasileira}

Percebemos que tanto essa divisão de atividade editorial quanto as variadas opiniões dos editores acerca dos gêneros de maior vendagem revelam certa má consciência em relação à galinha dos ovos de ouro dessa indústria. Nesse sentido, a resignação de José Olímpio sobre o romance policial é exemplar, pois ele pretendia seguir uma tendência não em função de suas diretrizes editoriais, mas do gosto do público. Porém, para ele, idealmente, "o povo necessita de um incentivo do governo, que o deveria educar, dirigindo a sua consciência artística. O 'prêmio Humberto de Campos', para contos, que criamos, tem esse objetivo". ${ }^{46}$ Considerava importante depurar o gosto literário do público numa direção determinada, na qual a editora fazia esforços particulares e projetava essa ação a ser encampada, em escala ampla, pelo governo. Três anos depois, em 1941, o representante da Livraria do Globo projetou esse ideal ao ser questionado sobre as tendências e níveis intelectuais do público:

Na sua opinião, o nível intelectual do leitor brasileiro melhora dia a dia. A grande massa está deixando de procurar o romance policial. Vai, aos poucos, trocando-o por leituras

\footnotetext{
${ }^{45}$ MICELI, Sérgio, op. cit., 2001b, p. 265-6, nota 27.

${ }^{46}$ O que se lê no Brasil, op. cit., 1938, p. 401.
} 
mais sérias, mais profundas. Isso não quer dizer que as tiragens da coleção Amarela diminuem. Absolutamente. Acontece, isto sim, que o aumento das coleções superiores é numa proporção que nada fica a dever aos romances de aventuras e mistérios. ${ }^{47}$

Essas projeções e desejos de intelectualização do leitor médio brasileiro poderiam vir acompanhadas de visões profundamente negativas sobre o papel desses gêneros na sociedade. Um artigo sobre a literatura infantil e sua relação com educação lamentava que as crianças também eram visadas pelos temas policiais: "o crime, o assalto, o roubo, o assassínio, o 'gangsterismo', a morte, a violência, tudo tem servido de enredo aos exploradores da literatura comercialmente rendosa". Para o autor Celso Barroso, além da literatura e do cinema hollywoodiano, esses temas começavam a se difundir também no rádio: "até as estações de rádio começam a explorar esse gênero de literatura, abrindo concurso entre a petizada, para que seja previsto o autor ou a autora de um crime de morte ou de um assalto a um estabelecimento bancário". Como solução, propunha "às autoridades e aos educadores impedi-la como medida de profilaxia intelectual e moral" porque, entre outras coisas, "impulsiona-se, com esses romances policiais gangsteristas, a alma da criança na direção do crime, do ódio, da aventura misteriosa, da guerra, da indisciplina e da desordem" ${ }^{48}$ Essa é a visão negativa mais comum contra a literatura policial, que pode ser estendida aos temas de aventura, pois se atribuía à sua narrativa um poder de sugestão que levaria o leitor a transpor para a realidade as situações da ficção e causar desordem social.

Outra visão negativa tinha menos argumentos de ordem social e mais cultural, reclamando contra tal literatura porque tomava o lugar das obras importantes para a formação dos jovens, como pode ser visto na opinião do editor da Edições Cultura Brasil:

A influência embrutecedora da novela policial na nossa adolescência, ainda não foi devidamente encarada pelas nossas autoridades e pelos nossos professores. Essa influência não é nefasta, como se assoalha, pelas possíveis perturbações psicológicas, pois acreditamos que a imensa maioria de seus leitores não se deixa perturbar por esse gênero de leitura. Tão só uma pequena minoria de enfermos será perniciosamente sugestionada. Ela é nefasta porque toma o lugar das obras verdadeiramente construti-

\footnotetext{
${ }^{47}$ As atividades editoriais de 1941. Folha da Manhã, 16/02/1941, p. 2.

${ }^{48}$ BARROSO, Celso. Literatura infantil, I. Folha da Manhã, 16/12/1937, p. 6.
} 
vas, daquelas que realmente concorrem para a formação do espírito. A novela policial atrasa a nossa cultura. ${ }^{49}$

Escritores e editores ligados ao ramo tinham posições menos radicais, ainda que olhassem o papel dos gêneros considerados de preferência do público sob as lentes da alta cultura. Nesse caso, era comum que os critérios de "profundidade" e "qualidade" fossem utilizados para seleção de obras para as coleções. Uma entrevista de José Olímpio após o lançamento da coleção "Grandes Romances para a Mulher" vai nesse sentido. José Olímpio julgava penetrar em um nicho de mercado novo ao conjugar numa única coleção o sentimentalismo de distração e a formação cultural, esta tendo como referência as duas grandes tendências do romance - social e intimista - na década de 1930. A conjugação, para ele, supria a dupla necessidade da "moderna mulher brasileira", portadora de outra mentalidade porque "a situação econômica permite a grande número de mulheres evitar o trabalho remunerado" e, por isso, "a mulher participa hoje espiritualmente da vida total, sem se limitar estritamente ao campo sentimental". Logo, "essa biblioteca estava fazendo falta no conjunto da bibliografia nacional, pois no Brasil a mulher lê habitualmente muito mais do que o homem e pede livro que, além de distrair, lhe alimente o espírito".50

Não foi exclusivo da José Olímpio esse movimento de saneamento. Na Folha da Noite, em 1943, o colunista R. Bloem comentou uma decisão da Globo sobre a coleção Amarela: "Ainda agora, a Livraria do Globo, de Porto Alegre, cuja coleção nesse gênero já se compõe de mais de cem volumes, informa que só serão incluídos nessa coleção, a partir do centésimo volume, livros que tenham sido premiados ou escolhidos em uma seleção rigorosa". ${ }^{51}$ É preciso uma análise detalhada para saber se tal seleção ocorreu de fato, mas não impedia que a proposta fosse utilizada para fins de propaganda, como vemos em um anúncio de jornal, de 1935, da nova fase da coleção Paratodos: "A mais seleta série de romances, de aventuras, de amor, policiais e históricos, dos mais eminentes autores estrangeiros. Literatura sã".52

No caso desses editores, a seleção visava mais estabelecer um padrão de gosto dentro dos próprios gêneros do que alterar o nível cultural das

\footnotetext{
${ }^{49}$ O que se lê no Brasil, op. cit., 1938, p. 402.

${ }^{5}$ QUEIROZ, J. B. Literatura para a mulher. Folha da Manhã, 30/6/1940, suplemento, p. II.

${ }^{51}$ BLOEM, R. A literatura policial. Folha da Noite, (Coluna à Margem dos Livros), 01/04/1943, p. 4.

${ }^{52}$ Folha da Manhã, 30 de maio de 1935, p. 11.
} 
coleções, porque consideravam que essa literatura tinha funções distintas das obras de referência literária. Os responsáveis pela Companhia Editora Nacional, valendo-se de uma autoridade crítica, comentavam que

é perfeitamente justificável a tendência que a massa quase geral do público sente por este gênero de literatura [policial, aventuras e sentimentais]. Diz um dos nossos mais eminentes críticos que este interesse vem da "necessidade de sonho, a premência de distrair a mente na oscilação igual da vida cotidiana, a procura daquilo que eles não vivem, aquilo que está além dos limites das suas existências pacíficas e metodizadas.".53

A necessidade de sonho ou distração não seria exclusiva da maioria do público. Numa propaganda da série Negra, os editores usam como estratégia atribuir o gosto pelo gênero policial a um dos ícones intelectuais do país: "Rui Barbosa lia os bons livros policiais e aconselhava aos seus amigos de trabalho intelectual como leitura de descanso cerebral". ${ }^{44}$ Nessa linha vai um comentário de Mathias Porto Velho, resenhista de livros das coleções da Companhia Editora Nacional para o jornal Folha da Manhã em 1934: "a literatura chamada de imaginação não faz mal a ninguém, ajuda o desenvolvimento da nossa própria imaginação e não é um mau remédio para os homens que trabalham excessivamente com o cérebro".55

Havia aqueles que defendiam esse tipo de literatura para além da distração, ressaltando também seu papel propedêutico, formativo, mas de maneira distinta da ficção de alta cultura. O próprio Mathias Porto Velho discordava dos "escritores patrícios, de julgamento precipitado, [que] chegam até a lamentar a vulgarização dessas obras em nossa língua" pois

\begin{abstract}
Ninguém, é claro, se inicia nos segredos da literatura e do gosto artístico, nas obras da grande arte. Uma obra prima de Milton, de Anatole, de Shakespeare, de Goethe é para o principiante tão inacessível como um tratado de cálculo integral para uma pessoa que nunca passou das quatro operações da aritmética (...) Aos livros de literatura popular estrangeira, devemos a procura sempre crescente dos livros dos nossos escritores. Esses romances policiais e de aventuras, tão malfadados por alguns, são a sinfonia de abertura para a compreensão de obras mais elevadas. ${ }^{56}$
\end{abstract}

\footnotetext{
53 O que se lê no Brasil, op. cit., 1938, p. 407.

${ }^{54}$ Folha da Manhã, 17/10/1937, suplemento, p. V.

55 VELHO, Mathias Porto. No mundo do livro. Folha da Manhã, 25/01/1934, 3a seção, p. 1.

56 VELHO, Mathias Porto. No mundo do livro. Folha da Manhã, 25/01/1934, 3a seção, p. 1.
} 
O colunista R. Bloem, da Folha da Noite aponta no mesmo sentido: "o livro policial, quando bem orientado, pode até mesmo ser útil sob mais de um aspecto. Primeiro, porque cria o hábito de ler, pois um bom livro policial, quando escrito por um Van Dine ou uma Agatha Christie, inegavelmente prende a atenção". E acrescenta uma observação sobre o aspecto moral, invertendo a posição que via nessas obras policiais uma incitação à desordem: "depois, porque no fim das contas, um livro desses representa, em geral, a luta do bem contra o mal". ${ }^{57}$ Para esses autores, tais gêneros estavam classificados em graus distintos de contribuição à formação cultural e moral, sendo concebidos como etapas iniciais que o público pouco familiarizado deveria percorrer até chegar às grandes obras do espírito. Além de refrescos para a mente, eram concebidos como cartilhas literárias.

Algumas opiniões observavam que se tratava de um modo diferenciado de fruir ficções. A divisão do mercado editorial está explícita num artigo de Clóvis Ramalhete intitulado "Os folhetins também têm direito", no qual refletiu sobre o lugar dos dois tipos de ficção. Para ele, a voga do que chama folhetim "não é propriamente uma orientação tomada por nossas letras, não é propriamente um fenômeno literário. É uma resolução de editores, tentados pela voga cinematográfica" que inspirava o público:

A cada volume novo, os leitores atiram-se às livrarias e somem-se as edições. Os editores compreendem que está aí o grande negócio. Enchem de cartazes coloridos e vistosos todos os muros e paredes do país. Assinam contrato para novas traduções do gênero, e preparam as máquinas impressoras. ${ }^{58}$

Mas a voga do romance popular traduzido ensejava o "protesto letrado, erudito, com intenções de profilaxia artística", nos quais o autor se incluía: "nós outros, que estamos de pé, do lado de cá da mesa, com um original de romance proustiano debaixo do braço, julgamos a coisa reles, comercial, e sobretudo perigosa para a formação do bom gosto da massa de leitores". Apontava que raros foram os momentos na história literária em que as duas formas de narrativas se cruzaram e, por isso, para apaziguar os seus colegas, vaticina:

\footnotetext{
${ }^{57}$ BLOEM, R. A literatura policial. Folha da Noite, (Coluna à Margem dos Livros), 01/04/1943, p. 4. E dá exemplo de livros do gênero: $O$ caso dos dez negrinhos de Agatha Christie.

${ }^{58}$ RAMALHETE, Clovis. Os folhetins também têm direitos. Anuário Brasileiro de Literatura, v. 5. Ed. Pongetti, 1941, p. 141.
} 
por todos os motivos, há duas histórias da literatura a se fazer: a do gosto das sociedades das épocas, com o sucesso de livraria consequente, e a outra, a que dá lugar a biografia em tratados colegiais, determinada por uma depuração de gosto, subjugada a oscilações de clima cultural das sociedades, cuja obra atinge, mais ou menos em cheio, um complexo sutil de interesses e qualidades que as imortalizam. - Mas nenhuma delas tem direito de excluir a outra de seu lugar sob o sol. ${ }^{59}$

A percepção da necessidade de distinção sem hierarquização entre dois padrões narrativos que remetam a gostos distintos também foi levantada anos antes em um artigo do Correio Paulistano. Aqui, todavia, o foco foi a relação do escritor com a crítica. F. Siqueira responde a um artigo que diagnosticava a necessidade de um crítico para um gosto literário brasileiro saudável, tendo em vista que o principal deles, Tristão de Athayde, passou a avaliar obras nacionais não pelos seus valores intrínsecos, mas a partir do seu catolicismo. ${ }^{60}$ Para Siqueira, o problema central não era a falta de críticos, mas de "um público para os escritores de renome e que veem as suas obras empoeirar-se nas estantes e nos sebos de todas as casas que comerciam com livros". Para chegar a essa conclusão, mencionou que o público leitor brasileiro estava aumentando, mas, por causa da dificuldade financeira, não teria condições de comprar livros a preços altos. Associava valor monetário a valor cultural, apontando que "os autores consagrados pela crítica não podem, a menos que queiram ser taxados de baixistas do próprio valor cultural, vender suas obras por preços ao alcance das bolsas mais modestas", obras essas caracterizadas por tratar de assuntos áridos, destinadas àqueles que têm sólida base de conhecimentos gerais ou para os eruditos.

Esta não era a realidade dos autores desconhecidos, considerados medíocres pela crítica, que "lograram descobrir o que desagrada e o que contenta a grande massa dos frequentadores das livrarias e das bibliotecas". Por isso, a necessidade de distinguir dois tipos de escritores, orientados por "críticas" diferenciadas:

Devemos, pois estabelecer duas classes de escritores: uma, os que escrevem para um pequeno público e ele é todo constituído por espíritos já mais ou menos formados; outra, os que escrevem para o grande público, para o povo, e são por ele compreendidos e disputados são os exemplares de suas obras. A estes escritores basta-lhes o

\footnotetext{
${ }^{59}$ RAMALHETE, Clovis. Os folhetins também têm direitos. Anuário Brasileiro de Literatura, v. 5. Ed. Pongetti, 1941, p. 141.

${ }^{60}$ ANDRADE, Rodrigo M. F. Precisa-se de um crítico. Folha da Manhã, 12/12/1934, p. 6.
} 
favor do público que os lê. A melhor crítica é a aceitação que os seus livros têm. Não necessitam da crítica pessoal e quase sempre eivada do espírito estreito de demolição ou de ocultos interesses. ${ }^{61}$

Como as outras opiniões, Clóvis Ramalhete e F. Siqueira consideravam mais importante para a formação do espírito cultivado aquilo que chamam "refinamento" literário. Mas seus curtos artigos não refletem sobre as funções das narrativas de agrado ao grande público para a formação literária, moral ou patriótica do leitor. No lugar, levantaram as tensões que trazem para o espaço do alto gosto literário, percebendo que se tratava de produção ficcional segundo outros parâmetros que não o da crítica especializada. Logo, um não é degrau para o outro. Daí apontarem a necessidade de diferenciar os dois sistemas de produção e fruição de narrativas veiculadas pelo suporte do livro: um deles efêmero, norteado pelo "sucesso" de livraria e pela aceitação do público anônimo, e outro dirigido a um restrito público com "espíritos já mais ou menos formados", aos quais cabe uma crítica personalizada, capaz de imortalizá-los nos manuais colegiais. Tendo como referência a esfera de bens culturais restritos, parecem reconhecer a independência e "o lugar ao sol" de uma literatura popular no Brasil.

Por vezes, a ênfase do debate recaía não sobre o aspecto "popular" desse tipo de literatura, mas sobre o nacional. A principal alegação dos editores para a tradução maciça de estrangeiros era a ausência do similar brasileiro que fosse de fácil leitura. O primeiro volume do Anuário Brasileiro de Literatura, de 1937, fez um levantamento sobre os "escritores estrangeiros cujas traduções são mais lidas no Brasil", apesar da existência de escritores notáveis por aqui. A razão é a mesma que José Paulo Paes apresentou meio século depois, o fato de os gêneros mais lidos, policial e para moças, serem "inteiramente descuidados entre nós", ou seja, "aqui ninguém quer fazer ou sabe fazer essas modalidades de literatura". ${ }^{62}$ É o mesmo diagnóstico feito pelo dono da Companhia Editora Nacional, Octales Marcondes, enquanto iniciava a edição de suas coleções, em 1931. O editor comenta ao jornal Folha da Noite que o novo interesse era o romance para moças, em substituição ao regionalismo da década anterior, cuja expressão maior continuava sendo Lobato. Indagado sobre os autores nacionais, comentou:

\footnotetext{
${ }^{61}$ SIQUEIRA, F. Falta de público. Correio Paulistano, 15/12/1934, p. 5.

${ }^{62}$ Escritores estrangeiros cujas traduções são mais lidas no Brasil. Anuário Brasileiro de Literatura, v. 1, 1937, p. 292-293.
} 
Os autores nacionais estão em crise. Há muito não aparece um livro nacional que consiga interessar ao público. Eles se queixam sempre do desinteresse com que são recebidos. Mas, srs., se os livros não prestam, como interessar os leitores? Tudo de bom que se edita sai, mais dia menos dia. Daí o interesse que têm despertado as traduções. Agora mesmo temos para lançar no mercado cento e tantas traduções. Neste caso dos autores nacionais, é bom você procurar por umas exceções salvadoras... ${ }^{63}$

Uma percepção análoga levava outro tradutor da editora, Agripino Grieco, a decretar a incapacidade nativa para os gêneros folhetinescos, em especial o policial

Há dias um amigo, exibindo-me um livro cheio de maquinações melodramáticas, redigido em nossa língua, declarou-me estar desconfiado de que o trabalho houvesse sido escrito por cidadão aqui da nossa terra, apesar da assinatura estrangeira. Não cheguei a percorrer o volume, mas creio que deve se tratar mesmo de tradução, porque os brasileiros nunca tiveram grande jeito para o trato do romance de aventuras. Como que a ternura da raça, o fácil sentimentalismo que nos compele ao fabrico de tantos poemas lamuriosos nos afasta das composições borradas de sangue, em que as personagens vão sendo chacinadas folha a folha, de modo a quase não sobrar gente para o epílogo ${ }^{64}$

Para ele, a questão não era que não houvesse no Brasil temas para esse tipo de literatura como, por exemplo, os subterrâneos do Morro do Castelo, ${ }^{65}$ o convento do Recife, o caso do capitão Mata Gente ${ }^{66}$ ou do roubo da joalheria Luiz Rezende na hora em que patrões e empregados dormiam. Para Grieco, os bons literatos como Alencar ou Bernardo Guimarães faziam com esses casos obras de alta literatura, e os maus estragavam a matéria. Citou como exemplo um escritor Gomes que "quis converter a minha pacata Paraíba do Sul em sítio de proezas romanescas, de aventuras noturnas, enchendo essa modesta cidade fluminense de uns tipos façanhudos de que ninguém nunca teve notícia por lá". Assim, à ausência de vocação para o gênero de aventuras, restaria aos brasileiros esperarem um escritor estrangeiro disposto a representar o país nos seus livros, como George Simenon que

ficou de aparecer por aqui, no iate em que corre todos os mares, e, com a sua visita, é provável que tenhamos um bom romance policial localizado no Brasil. Porque é ele

\footnotetext{
${ }_{63}$ O Rio é o melhor mercado de livros do Brasil. Folha da Noite, 09/12/1931, p. 1.

${ }^{64}$ GRIECO, Agripino. Literatura de sensação. Folha da Manhã, 14/10/1934, p. 6.

${ }^{65}$ Parecia não conhecer as reportagens de Lima Barreto.

${ }^{66}$ A história de um fazendeiro acusado de matar comerciantes e credores que entravam em suas fazendas. Cf. GRIECO, Agripino. Literatura de sensação. Folha da Manhã, 14/10/1934, p. 6.
} 
dos que aproveitam todos os cenários e figurantes das regiões que vai conhecendo. Reduz tudo a papel impresso e, como seu balcão é dos mais afreguezados, a cédulas do Tesouro. ${ }^{67}$

A mesma percepção poderia tomar outros rumos. O escritor Menotti Del Picchia foi um dos que aceitaram o desafio de verdeamarelizar os gêneros populares, começando pelas aventuras. Lançou em 1930 o livro intitulado República 3000, posteriormente rebatizado para A filha do inca, e, em 1936, lançou Kalum, o mistério do sertão. Atento ao movimento editorial, Menotti explicita o projeto no prefácio deste romance:

O número de traduções de livros de aventuras destinados ao público brasileiro inunda o mercado. A procura que encontra tais volumes demonstra a preferência dos leitores nacionais pelo gênero. Os escritores nossos, sempre acastelados na sua "torre de marfim", reclamam contra a invasão mental forasteira, mas não descem das suas estelares alturas para dar ao leitor indígena o que ele pede. Esse orgulho está errado. Escrever romances populares é prestar ao país um duplo serviço: é nacionalizar sempre mais o livro destinado às massas e abrasileirar nossa literatura, imergindo a narrativa, que distrai e empolga, em ambiente nosso. É essa a melhor forma de se socializar o espírito da nossa gente e nossa paisagem. ${ }^{68}$

Menotti Del Picchia retomou sob uma chave nacionalista vários dos termos das opiniões correntes nos anos 1930 sobre essa ficção. Considerou a divisão entre o gosto dos intelectuais e do mercado, com o isolamento dos primeiros, apontou as reclamações contra o livro estrangeiro, mas não se satisfez com as soluções de repeli-los ou aceitá-los. Proclamou uma postura saneadora não mais do gosto, que aceitou como inevitável pelo público, mas do conteúdo exógeno. Para ele, não apenas os leitores sairiam ganhando ao terem à disposição uma empolgante narrativa ambientada no seu próprio país. No prefácio do volume, o autor deixou claros os propósitos cívicos, apontando a ameaça dos livros estrangeiros que abarrotavam o mercado: "os moços começam a pensar e a agir sob a influência desnacionalizante de tais narrativas, descaracterizando-se nossos usos pela presença nelas de um sugestivo panorama e de tipos completamente alheios à nossa paisagem geográfica e humana". Então o escritor, além de ter à disposição um mercado aberto com a "nacionalização" dos gêneros mais vendidos, iria prestar um

\footnotetext{
${ }^{67}$ GRIECO, Agripino. Literatura de sensação. Folha da Manhã, 14/10/1934, p. 6.

${ }^{68}$ PICCHIA, Menotti Del. Prefácio a Kalum (1936). In: Idem. Obras completas, v. 4. Rio de Janeiro: A Noite, 1946, p. 139.
} 
enorme serviço à pátria. Bastaria apenas descer, de vez em quando, da estelar torre de marfim da alta literatura, que estaria sempre lá para quando quisesse novamente subir.

Um escritor hoje pouco conhecido, João de Minas, apostou sua carreira literária nesse filão que se abria, radicalizando as posições de Menotti Del Picchia e preenchendo suas lacunas. Valendo-se de um populismo literário vergado de anti-intelectualismo, atuou nos gêneros mais vendidos da década com uma série de livros: aventuras (Mulheres e monstros - 1933; Horrores e mistérios nos sertões desconhecidos - 1934; Pelas terras perdidas - 1934), sentimental com tintas pornográficas para a época (A mulher carioca aos 22 anos - 1934; A datilógrafa loura - 1934; Uma mulher... mulher!; Fêmeas e santas - 1935; A prostituta do céu - 1935), e policial (Nos misteriosos subterrâneos de São Paulo - 1936). Em curta crônica publicada em 1935, respondeu a uma crítica feita a um livro recém-lançado nos seguintes termos:

Há semanas um eminente crítico literário, tratando de um livro meu, creio que nas colunas d' A Noite, recordou minha estreia literária.

Eu teria estreado escrevendo bonito, falando doutor, cheio de estilo... E agora - segundo o nobre crítico - eu escrevo fácil com uma agilidade jornalística, o que para o honrado mestre é um crime.

Acha S. Ex. que o escritor direito, familiar, de colarinho limpo etc. é o gajo que escreve escuro, pesado e encaracolado. Como esse fulgurante pobre diabo que foi o dr Euclides da Cunha, suponhamos, um homem que apenas com um rijo livro tem feito dormir o Brasil inteiro.

Não. Eu prefiro ser leve, fácil, jornalístico... e lido. Prefiro ser como agora.

Um fato curioso. Quando faleceu João Ribeiro, meu amigo escritor imenso, eu fiz uma enquete popular, perguntando aos humildes se eles conheciam o saudoso acadêmico. Quase ninguém o conhecia.

Eu ainda me lembro que tive medo dessa glória maravilhosa... de que o povo absolutamente não tem notícia.

Donde se conclui que o escritor sublime alfabetiza pouco as massas, sendo só lido por uma meia dúzia de sábios e críticos pavorosos. Ora, o mundo coletiviza-se vertiginosamente. Logo, o escritor que se isola nas igrejinhas miríficas suicida-se.

Os livros brasileiros até há pouco sofriam uma bruta concorrência dos ditos estrangeiros, por isto: o nosso livro não tinha o que se ler, no sentido fácil e popular; fazíamos muito estilo, discutíamos escolas literárias, brigávamos, perdidos no fundo de grêmios, 
academiazinhas, fundações, num sifilítico babuzar de elogio mútuo... Ora, o povo - ou as classes - não querem saber disso.

Eu fugi desse caminho burro. Resolvi fundar o romance popular no Brasil. E tenho pena dos rapazes mentecaptos e importantes, aqueles!...99

Na desaforada crônica em resposta a uma crítica de um livro seu está registrada a apostasia literária de João de Minas. O autor explicitamente atacou o sistema de legitimidade vigente renegando o mundo da alta literatura, no qual se praticava, para ele, desde o elogio mútuo até as discussões e brigas em torno de escolas literárias, todos visando a glória dos pares, valendo-se de um estilo obscuro, pesado e encaracolado, incompreensível para a maioria. A linguagem oscilante entre a ofensa ("críticos pavorosos", "mentecaptos") e a ironia ("glória maravilhosa", "importantes, aqueles!") acentua o tom polêmico. O escritor mineiro atacou a crítica literária que canoniza romances profundos porque achava que a alta cultura definharia por ausência de público, sendo substituída por um padrão de julgamento das obras coletivo e anônimo, a aceitação medida pelo índice de vendas, ser conhecido entre os humildes, receber cartas de fãs etc.

Sua posição inverte o sinal das falas até aqui analisadas. O problema não era relegar ou aceitar o papel cultural secundário ou paralelo da literatura de aventuras, policial ou sentimental. Em função da mudança social que julgava se operar, com a emergência de uma nova camada de leitores propulsora do dinamismo do mercado editorial, o estabelecimento dos gêneros populares teria estatuto de fato. Por isso, a "alfabetização das massas" implicava a subordinação do escritor ao gosto do grande público, e não o contrário. A descrença na perenização cultural e a perspectiva de lucros econômicos ou simbólicos levou-o a questionar o papel da forma de leitura e produção de narrativas mediada pela crítica pessoalizada. Inspirado pelos pensamentos dos políticos europeus e brasileiros dos anos 1920 e 1930, e atento ao desenvolvimento da ficção popular no país e no mundo, João de Minas sonhava com a comunicação direta com as massas.

\section{Considerações finais}

Frente ao aumento do público leitor e à expansão da indústria editorial brasileira nos anos 1930, os livros de aventura, policial e sentimental tra-

\footnotetext{
${ }^{69}$ MINAS, João de. Cartas mineiras de São Paulo. Gazeta de Notícias, Rio de Janeiro, 17/02/1935, p. 5.
} 
duzidos se tornaram um dos sinônimos de romance ou literatura popular, de imaginação, evanescente, folhetim - os termos "literatura de massa" ou "literatura de entretenimento" não circulavam. Tais gêneros foram considerados populares no sentido de best-sellers (por serem os mais procurados pelo público e, logo, lucrativos ao editor), tanto pelos enredos repletos de lances imaginosos capazes de despertar emoções e prender o leitor, como por sua prosa de fácil leitura - ou, numa vaga definição da época, “aquelas obras de ficção que ele [o povo] facilmente lê e compreende sem o auxílio do dicionário". ${ }^{70}$ É neste sentido que Octales Marcondes, editor de coleções de livros traduzidos, bem como João de Minas e Menotti Del Picchia, escritores que se propuseram a nacionalizar esses gêneros, diziam que faltava no Brasil uma literatura "no sentido fácil e popular".

Todos os que trataram do tema assistiam transformações centrais para o país, seja a difusão de novas mídias de massa como o rádio e o cinema falado, seja a expansão do mercado editorial, a qual dava concretude às utopias de criação, nos trópicos, de uma civilização fundada na cultura letrada de expressão nacional, para as quais parte dos intelectuais reclamava apoio do Estado recriado e fortalecido após 1930 . Porém, a maior parcela da ficção vendida e lida escapava ao modelo didático e literário almejado, lançando sombras sobre aquela utopia, tendo em vista que o fenômeno era mais editorial que erudito, nas palavras de um observador da época. Como vimos, a questão dos gêneros populares girou em torno de dois eixos, o civilizacional e o nacional.

A maior parte dos comentários dos editores e escritores tinha como referência o padrão da alta literatura brasileira ou estrangeira que, na concepção deles, se caracterizava por romances com enredos complexos e linguagem elaborada que abordassem embates psicológicos e/ou sociais. Na tentativa de apreender o fenômeno da expansão dos gêneros mais vendidos de ficção, suas opiniões quase sempre lhes atribuía um valor literário menor e lhes reservava um lugar subalterno no campo geral da ficção. Para aqueles que os consideravam uma ameaça à ordem social ou à difusão daquela alta cultura, seu lugar era a lata do lixo, devendo ser combatidos ou, no mínimo, saneados. Para os olhares mais simpáticos, teriam seu lugar nas estantes, fosse pelo papel de diversão, de formação da leitura em um público ainda não familiarizado, de vetor de difusão do patriotismo - caso a nacionalização desses gêneros fosse bem sucedida -, ou ainda um campo a mais - campo

\footnotetext{
${ }^{70}$ SIQUEIRA, F. Falta de público. Correio Paulistano, 15/12/1934, p. 5.
} 
virgem e promissor - para a atuação do escritor brasileiro. Tanto os sonhos mais otimistas quanto os pesadelos dos escritores em relação a essa ficção procuravam lidar com a percepção problemática de que se formava no país uma sociedade de massas cujo gosto não se direcionava aos padrões eruditos e/ou nacionais.

Este artigo contribui com a reconstituição das condições sociais e culturais que levaram à emergência de categorizações das obras voltadas ao grande público nos anos 1930 e início de 1940, as quais hoje são classificadas como "popular", de "massa" ou de "entretenimento". Como exemplo da relevância da tarefa, é curioso notar que já estavam presentes nos anos 1930 questões como a função de "degrau" da literatura de entretenimento para a formação de um público erudito, a suposta (e desmentida) incapacidade brasileira de atuar nesses gêneros, a relação nacional x estrangeiro no debate sobre os best-sellers, e a excessiva valorização da alta literatura. Tais questões foram levantadas como novidade por José Paulo Paes nos anos 1980, que, ainda na segunda década do século XXI, estão presentes no Manifesto Silvestre $^{71}$ e na "Geração Subzero".72 Além disso, ao esboçar um mapa do terreno, nem mesmo José Paulo Paes soube da pretensão de João de Minas, meio século antes, de se tornar referência nesse filão.

Como já disse naquela época Clóvis Ramalhete, e parodiando o próprio Paes, daí a importância de uma vigorosa, crítica e coletiva história (da cons-

\footnotetext{
${ }^{71}$ É um manifesto lançado em 2010 em defesa da literatura de entretenimento, cujo mote inicial é: "1. Em literatura, entretenimento não é passatempo. É sedução pela palavra. / 2. Tudo é linguagem, mas a narrativa é a base da literatura. Uma história bem contada é o objetivo que perseguimos." Daí a defesa do acesso da ficção brasileira a uma parcela maior da população e a denúncia dos experimentalismos "vazios" da linguagem, que limitavam a literatura "a uma elite que dita regras, cria rótulos e se autoenaltece em resenhas mútuas, eventos e panelas". Foi assinado por Lucia Bettencourt, Ângela Dutra de Menezes, Celina Portocarrero, Luis Eduardo Matta, Felipe Pena, Thomaz Adour, Bárbara Cassará, Halime Musser, Ana Cristina Mello, Marcela Ávila. Ver Manifesto Silvestre pela popularização da ficção. O Globo, Rio de Janeiro, 27/2/2010. Disponível em: http://oglobo.globo.com/blogs/prosa/posts/2010/02/27/manifestodo-grupo-silvestre-pela-popularizacao-da-ficcao-269830.asp. Acesso em: 14/09/2014.

72 "Geração Subzero - 20 autores congelados pela crítica, mas adorados pelos leitores". Organizada em 2012 por Felipe Pena e lançada pela Record (Rio), é uma antologia com autores voltados ao entretenimento. O título e a própria antologia são uma paródia de outra obra organizada por Nelson Oliveira, Geração zero-zero, que ambicionava apresentar os melhores autores brasileiros surgidos nos anos 2000. O acaso deu uma ajuda para estabelecer outra paródia involuntária, incorporada à orelha do livro, pois Geração Subzero foi lançada simultaneamente à antologia Granta 9 - os melhores jovens escritores brasileiros, resultado de um concurso para eleger os melhores escritores com menos de quarenta anos, organizado pela versão em português daquela revista literária britânica.
} 
tituição) da literatura para o grande público, suas categorias, significados e debates mobilizados em cada período, pois tal história pode iluminar, de diversos ângulos, as narrativas que formavam sensibilidades, tocando mentes e corações de expressivo número de leitores.

\section{Referências de artigos dos anos 1930-40}

AMADO, Jorge. A situação do livro e do escritor (entrevista a José Lins do Rego). Folha da Manhã, 24/12/1935, p. 6.

ANDRADE, Rodrigo M. F. Precisa-se de um crítico. Folha da Manhã, 12/12/1934, p. 6.

As atividades editoriais de 1941. Folha da Manhã, 16/02/1941, p. 2.

BARROSO, Celso. Literatura infantil, I. Folha da Manhã, 16/12/1937, p. 6.

Biblioteca "para inglês ver". Gazeta de Notícias, Rio, 19/06/1941, p. 6.

BLOEM, R. A literatura policial. Folha da Noite, (Coluna à Margem dos Livros), 01/04/1943, p. 4.

Catálogo da Companhia Editora Nacional publicado na Folha da Manhã, 22/10/1933, p. VII, suplemento.

Escritores estrangeiros cujas traduções são mais lidas no Brasil. Anuário Brasileiro de Literatura, vol. 1. Ed. Pongetti, 1937, p. 4292-293.

GRIECO, Agripino. Literatura de sensação. Folha da Manhã, 14/10/1934, p. 6.

LIMA, Hermes, Terra-mar-e-ar. Folha da Manhã, 29/04/1933, p. 6.

Literatura nociva. Gazeta de Notícias, Rio, 11/05/1937, p. 3.

MINAS, João de. Cartas mineiras de São Paulo. Gazeta de Notícias, Rio de Janeiro, 17/02/1935, p. 5.

O que se lê no Brasil. Anuário Brasileiro de Literatura, v. 2. Ed. Pongetti, 1938, p. 401-8.

O Rio é o melhor mercado de livros do Brasil. Folha da Noite, 9/12/1931, p. 1.

PICCHIA, Menotti Del. Prefácio a Kalum (1936). In: Idem. Obras completas, v. 4. Rio de Janeiro: A Noite, 1946.

Propaganda da coleção SIP. Folha da Manhã, 26/04/1934, p. 13.

Propaganda da coleção Paratodos, Folha da Manhã, 30 de maio de 1935, p. 11.

Propagandas da série Negra. Folha da Manhã, 08/08/1934, p. 11.

Propaganda da série Negra. Folha da Manhã, 17 de outubro de 1937, suplemento, p. V.

Que lê o carioca. Diário Carioca, 23/03/1938, p. 3 e 12.

QUEIROZ, J. B. Literatura para a mulher. Folha da Manhã, 30/6/1940, suplemento, p. II. 
RAMALHETE, Clovis. Os folhetins também têm direitos. Anuário Brasileiro de Literatura, v. 5. Ed. Pongetti, 1941, p. 141.

SIQUEIRA, F. Falta de público. Correio Paulistano, 15/12/1934, p. 5.

VELHO, Mathias Porto. O mundo dos livros. Folha da Manhã 01/03/1934, p. 5. . No mundo do livro. Folha da Manhã, 25/01/1934, $3^{\text {a }}$ seção, p. 1.

\section{Referências bibliográficas}

AMORIM, Sônia Maria. Em busca de tempo perdido: edição de literatura traduzida pela Editora Globo (1930-1950). São Paulo: Edusp, ComArte; Porto Alegre: Editora UFRGS, 1999.

ALBUQUERQUE, Paulo. O mundo emocionante do romance policial. Rio de Janeiro: Francisco Alves, 1979, cap. 15.

BARBOSA, Marialva. História cultural da imprensa: Brasil - 1900-2000. Rio de Janeiro: Mauad X, 2007.

BEDA, Ephraim de Figueiredo. Octalles Marcondes Ferreira: formação e atuação do editor. Dissertação de mestrado, ECA-USP, São Paulo, 1987.

BULHÕES, Marcelo. Jornalismo e literatura em convergência. São Paulo: Ática, 2007.

CAUSO, Roberto de Sousa. Fiç̧ão científica, fantasia e horror no Brasil (1875-1950). Belo Horizonte: UFMG, 2003.

COSTA, Cristiane. Pena de aluguel: Escritores jornalistas no Brasil - 1904 a 2004. São Paulo: Companhia das Letras, 2005.

DUTRA, Eliana Freitas. Mediação intelectual e percursos da cultura no Brasil dos anos 1930: o caso da coleção Brasiliana e da Cia Editora Nacional. In: RODRIGUES, Helenice $\mathcal{E}$ KOHLER, Heliane (org.). Travessias e cruzamentos culturais: $a$ mobilidade em questão. Rio de Janeiro: FGV, 2008.

EL FAR, Alessandra. Páginas de sensação: literatura popular e pornográfica no Rio de Janeiro (1870-1924). São Paulo: Companhia das Letras, 2004.

HALLEWELL, Laurence. O livro no Brasil. São Paulo: Edusp, 2005.

IBGE. Estatísticas do século XX. 2003. Disponível em: http://www.ibge.gov.br/ seculoxx/arquivos_pdf/populacao/1936/populacao1936aeb_13.pdf. Acesso em: 14/07/2012.

KOSHIYAMA, Alice. Monteiro Lobato: intelectual, empresário, editor. São Paulo: Edusp / ComArte, 2006.

LUCA, Tânia Regina de $\mathcal{E}$ MARTINS, Ana Luíza (org.). História da imprensa no Brasil. São Paulo: Contexto, 2008.

MEYER, Marlise. Folhetim: Uma história. São Paulo: Companhia das Letras, 1996.

MICELI, Sérgio. Poder, sexo e letras na República Velha (estudo clínico dos anatolianos). In: Idem. Intelectuais à brasileira. São Paulo: Companhia das Letras, 2001a. Intelectuais e classe dirigente no Brasil (1920-1945). In: Idem. Intelectuais à brasileira. São Paulo: Companhia das Letras, 2001b (1979). 
NAGLE, Jorge. A educação na Primeira República. In: FAUSTO, Boris (org.). História geral da civilização brasileira - o Brasil republicano, tomo 3, v. 2. Rio de Janeiro/São Paulo: Difel, 1978.

ORTIZ, Renato. A moderna tradição brasileira. São Paulo: Brasiliense, 1988.

Sociedade e cultura. In: SACHS, Ignacy et alii. Brasil: um século de transformações. São Paulo: Companhia das Letras, 2001, p. 186-209.

PAES, José Paulo. Por uma literatura brasileira de entretenimento In: Idem. $A$ aventura literária. São Paulo: Companhia das Letras, 1990, p. 25-38.

REIMÃO, Sandra. Sobre a noção de best-seller. Comunicação e Sociedade. São Paulo: Instituto Metodista de Ensino Superior (IMS), ano X, nº 18, 1991, p. 53-60. Literatura policial brasileira. Rio de Janeiro: Zahar, 2005.

SALIBA, Elias Thomé. Raízes do riso. São Paulo: Companhia das Letras, 2002.

SAVIANI, Demerval. História das ideias pedagógicas no Brasil. Rio de Janeiro: Bertrand Brasil, 2008.

SOARES, Gabriela Pellegrino. Semear horizontes: uma história da formação de leitores na Argentina e no Brasil, 1915-1954. Belo Horizonte: Editora UFMG, 2007.

SORÁ, Gustavo. Brasilianas. José Olympio e a gênese do mercado editorial brasileiro. São Paulo: Edusp / ComArte, 2010.

TORRESINI, Elisabeh Rochadel. Editora Globo: uma aventura editorial nos anos 30 e 40. São Paulo: Edusp, ComArte; Porto Alegre: Editora UFRGS, 1999. 
